\title{
Air Temperature Shield Tests
}

\author{
by
}

Richard E. Payne

Woods Hole Oceanographic Institution

Woods Hole, Massachusetts 02543

October 1987

\section{Technical Report}
Funding was provided by the National Science Foundation under grant Numbers OCE 81-22061 and OCE 82-11108, and by the Office of Naval Research under contract Number N0O014-84-C-0134.

Reproduction in whole or in part is permitted for any purpose of the United States Government. This report should be cited as: Woods Hole Oceanog. Inst. Tech Rept., WHOI-87-40.

Approved for publication; distribution unlimited.

\section{Approved for Distribution:}

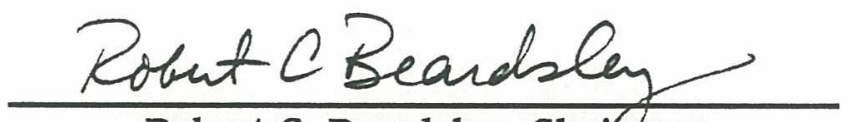

Robert C. Beardsley, Chailman Department of Physical Oceanography 


\begin{abstract}
Measurements were made with a group of sensors for 37 days at the end of a dock in Vineyard Sound. The sensors included: a thermistor in an R. M. Young aspirated air temperature radiation shield, a thermistor in an R. M. Young multiplate shield, wind speed and direction, and solar irradiance. For the last eight days we also included a WHOI built cylindrical radiation shield. For wind speeds above $2 \mathrm{~m} \mathrm{~s}^{-1}$, the multiplate shield had an RMS error relative to the aspirated shield of $0.2-0.3 \mathrm{C}$ during daylight hours. Adding a correction linear in solar irradiance decreased the error by a factor of one third to one half. The cylindrical shield appears to have performed better than this but there was insufficient data to support this conclusion statistically.
\end{abstract}




\begin{tabular}{|c|c|}
\hline & Page \\
\hline Abstract & $i$ \\
\hline Table of Contents & $\mathrm{ii}$ \\
\hline Introduction & 1 \\
\hline Test Environment & 1 \\
\hline Digitization and Recording & 1 \\
\hline Sensors and Shields & 3 \\
\hline The Data & 5 \\
\hline Data Analysis & 11 \\
\hline Conclusions & 20 \\
\hline References & 22 \\
\hline
\end{tabular}


Introduction

For remote locations, such as buoys, where electrical power is precious, the use of static shields to protect air temperature and relative humidity sensors from solar radiation is necessary rather than forced aspiration of the sensor. The degree of protection afforded by these shields, however, depends on sun altitude, solar radiation flux, wind speed, and long wave radiation from their immediate environment.

Because of the manufacturer's performance specifications, convenience of mounting our sensors, and cost, we selected R. M. Young's Model 41001 Gill multiplate radiation shield to house both air temperature and relative humidity sensors for the Meteorological Recorder (MR) (Payne, 1987). In order to obtain an indication of their performance under reasonably realistic conditions, we carried out the informal test described in this report. A second type of shield, built at WHOI (Woods Hole Oceanographic Institution), was added during the last nine days of the test.

\section{Test Environment}

Figure 1 shows a small pier which projects about $25 \mathrm{~m}$ into Nantucket Sound. The wooden framework at the end was added for the purposes of the radiation shield test. The shore runs roughly east-west so that the prevailing southwest wind is onshore. The closest land to the $\mathrm{SW}$ is several miles away. The end of the dock thus provides a suitable marine environment for testing buoy instrumentation.

\section{Digitization and Recording}

Digitization and recording were accomplished with a standard MR. Analog data were averaged over 64 digitizations per 7.5 minute recording interval. The AIR barometer transferred a digital pressure to the MR. The wind processor computed vector components digitally and passed them to the MR. The data were recorded on digital cassettes. About once per week the tapes were changed and the data processed. 

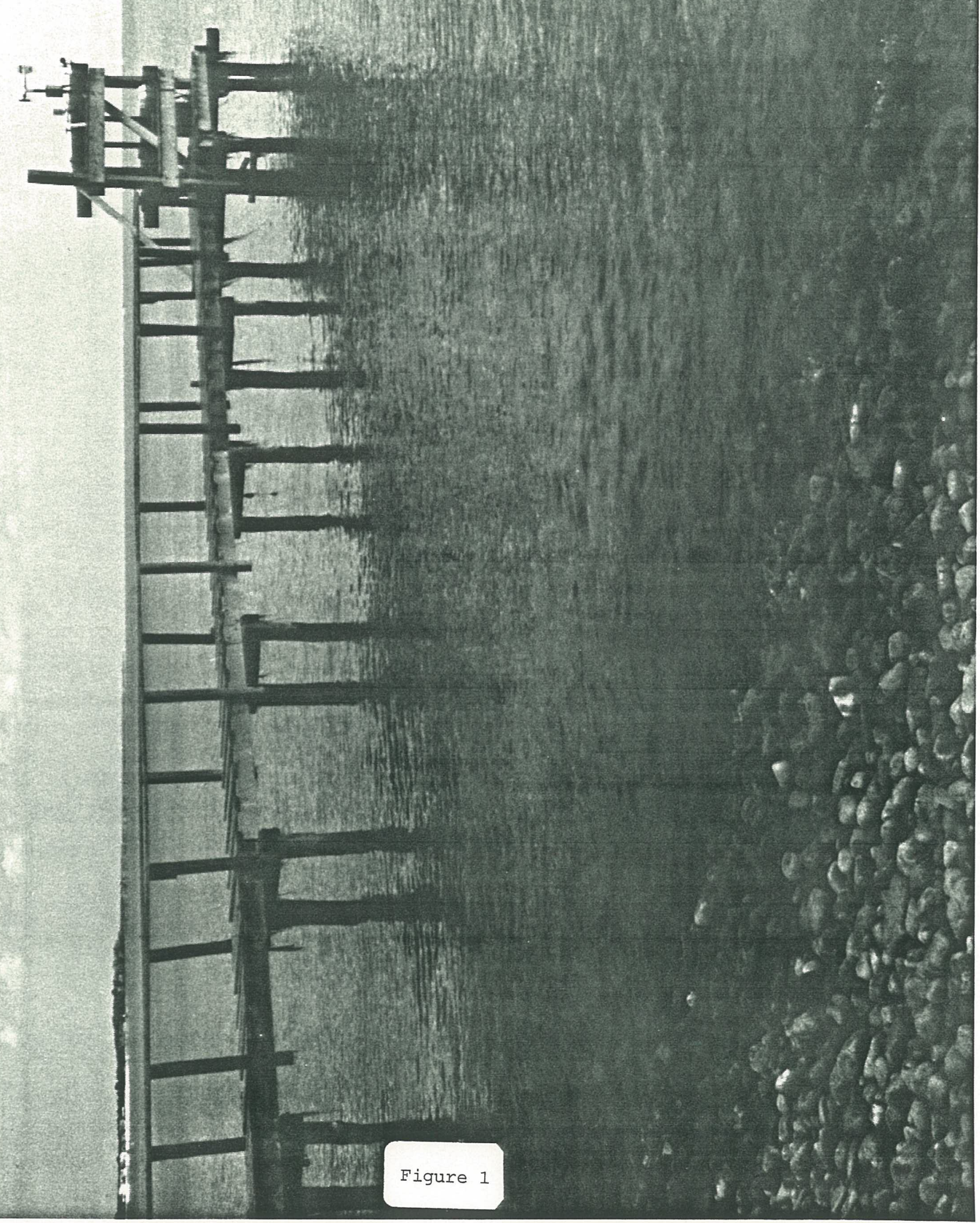
Sensors and Shields

Figure 2 shows the sensors as mounted on the pier. From left to right are the pyranometer, a static port for the AIR barometer, the Gill Multiplate radiation shield, a Gill-Aspirated radiation shield, a Young wind monitor atop a housing containing digital vector averaging electronics, and a WHOI-constructed radiation shield designed by J. Dean which we refer to as the Dean shield. Temperature sensors in all three radiation shields are YSI thermistors.

The R. M. Young Model 43404A Gill-Aspirated Temperature Radiation Shield provided the reference air temperature. Manufacturer's specifications state that, using the supplied fan to supply an air flow of $3 \mathrm{~m} \mathrm{~s}^{-1}$, the sensor is maintained within +-.05 C of true air temperature. Unfortunately, the R. M. Young supplied fan requires 110 VAC which was not available on the pier. We substituted a 12 VDC fan which was able to maintain an air flow of only $0.7 \mathrm{~m} \mathrm{~s}^{-1}$. We do not know how much this degraded the performance. The sensor is surrounded by a vacuum bottle, silvered on the inside surfaces The bottle is open at the bottom end. Gerald Gill found in wind tunnel tests (R. M. Young, personal communication) that at low wind speeds, intense infrared radiation from below could increase the apparent air temperature by as much as $1.5^{\circ} \mathrm{C}$. In our situation the bottle opening pointed straight down at the water surface and we expect little error from admitted radiation except for clear sky and high sun when sun glitter may have been reflected into it. We cannot estimate the possible degradation in accuracy from this but, since the other shields are independent of this effect, we would expect to see anomalously high values of aspirated air temperature if this effect were significant. We do not.

The Young multiplate shield is designed to prevent direct solar radiation from reaching the sensor and to provide several layers of plates, with spaces between for air to circulate freely, to minimize the effects of long wave radiation from the uppermost and lowermost plates on the sensor. The plates are molded of plastic. The thermistor is potted in a $1 / 4$ " bolt which screws into a Delrin cylinder. There is approximately 1/16" of plastic between the bolt and ambient air. The thermistor is calibrated to an accuracy of 0.0lC absolute (Payne et al., 1976). We estimate that self heating, 


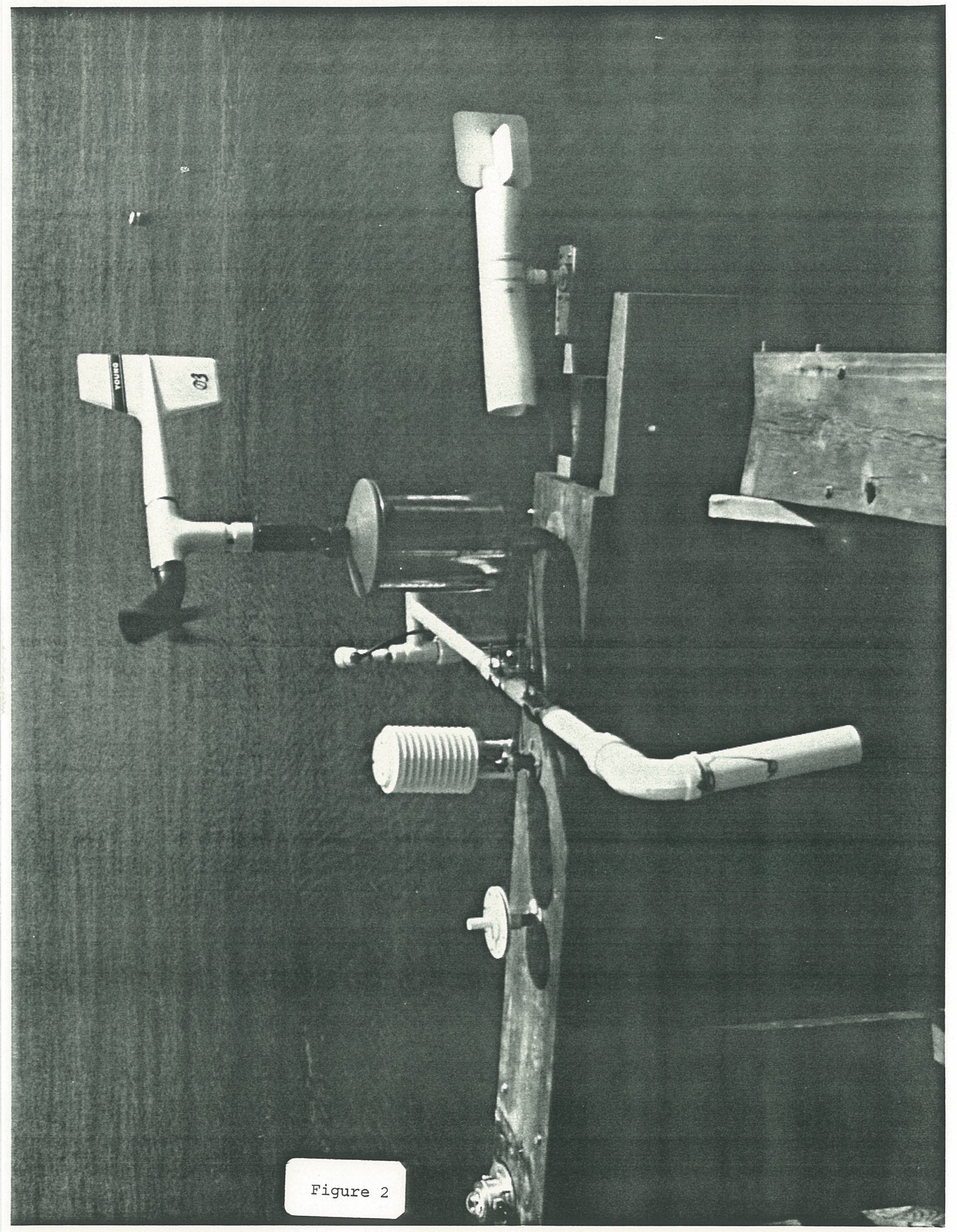


digitization, and analog electronics (Payne, 1987) increase the uncertainty to $0.05 \mathrm{C}$.

The Dean radiation shield, described fully in Dean and Beardsley (1987), is built of three concentric tubes, one each of Surlyn, PVC and aluminum from the outside in. It was designed to act as a wind vane, pivoting freely to stay aligned into the wind to allow direct air flow across the temperature sensor and between the tubes. The thermistor used was similar to those in the multiplate shields and was also calibrated to $0.01 \mathrm{C}$.

The pyranometer is an Eppley Model 8-48. Due to foreshortening in the photograph it appears to be closer to the other sensors than it was. They were all quite low in its field of view. We estimate that the irradiance measurements were accurate to about $5 \%$.

The R. M. Young Model 5102 Wind Monitor was mounted on a housing which contained a microprocessor-based wind processor (WP). On buoy deployments the WP contains a magnetic compass. On the pier we hardwired a compass reading of " $O$ " and aligned the case to magnetic north. The WP computes vector components for each propeller revolution (30 cm of air) and sums them over the recording interval, giving a true vector average. R. M. Young indicates that accuracies are approximately $\pm 2 \%$ in wind speed and \pm 2 degrees in wind direction.

Barometric pressure measurements were not used in the analyses in this report.

\section{The Data}

Data recording began at 2036 UTC on 20 August 1985 and continue until 1745 UTC on 25 september. The Dean shield thermistor was attached to the MR midday, 17 september. Wind speed is missing for about six days. The data from a 24 hour period between 10-11 september were deleted because the battery driving the aspirator fan motor failed. Figure 3 shows the periods of good data for the various sensors. Overall there were about 34 days of 7.5 minute averages, a total of 6664 records. Of these, 1564 contain Dean shield data.

All data were processed with the standard MR program suite and edited. Bad values were replaced with linear interpolated values. Figures 4-7 show the data. The parameter labels are defined below under Data Analysis. 


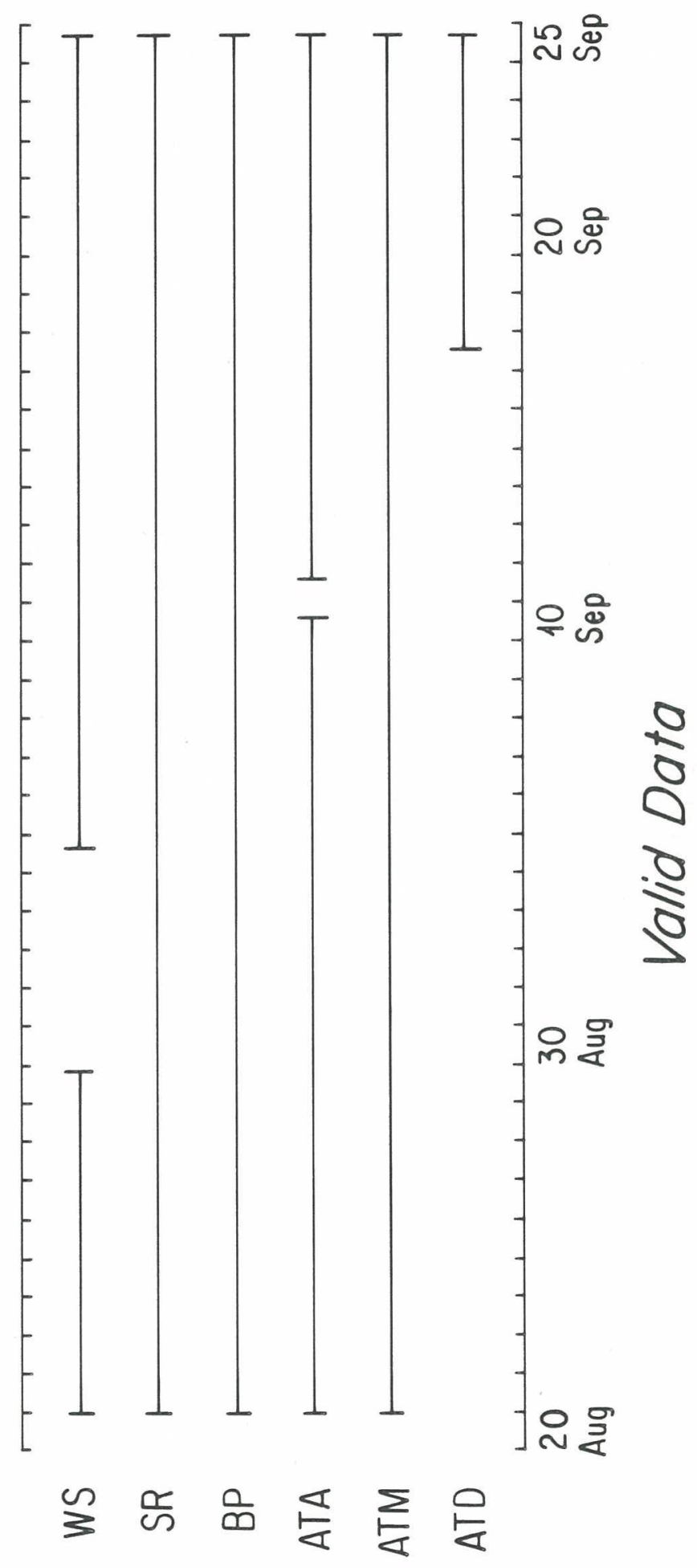

Figure 3 
AT SHELD MTERCOMPAPASON
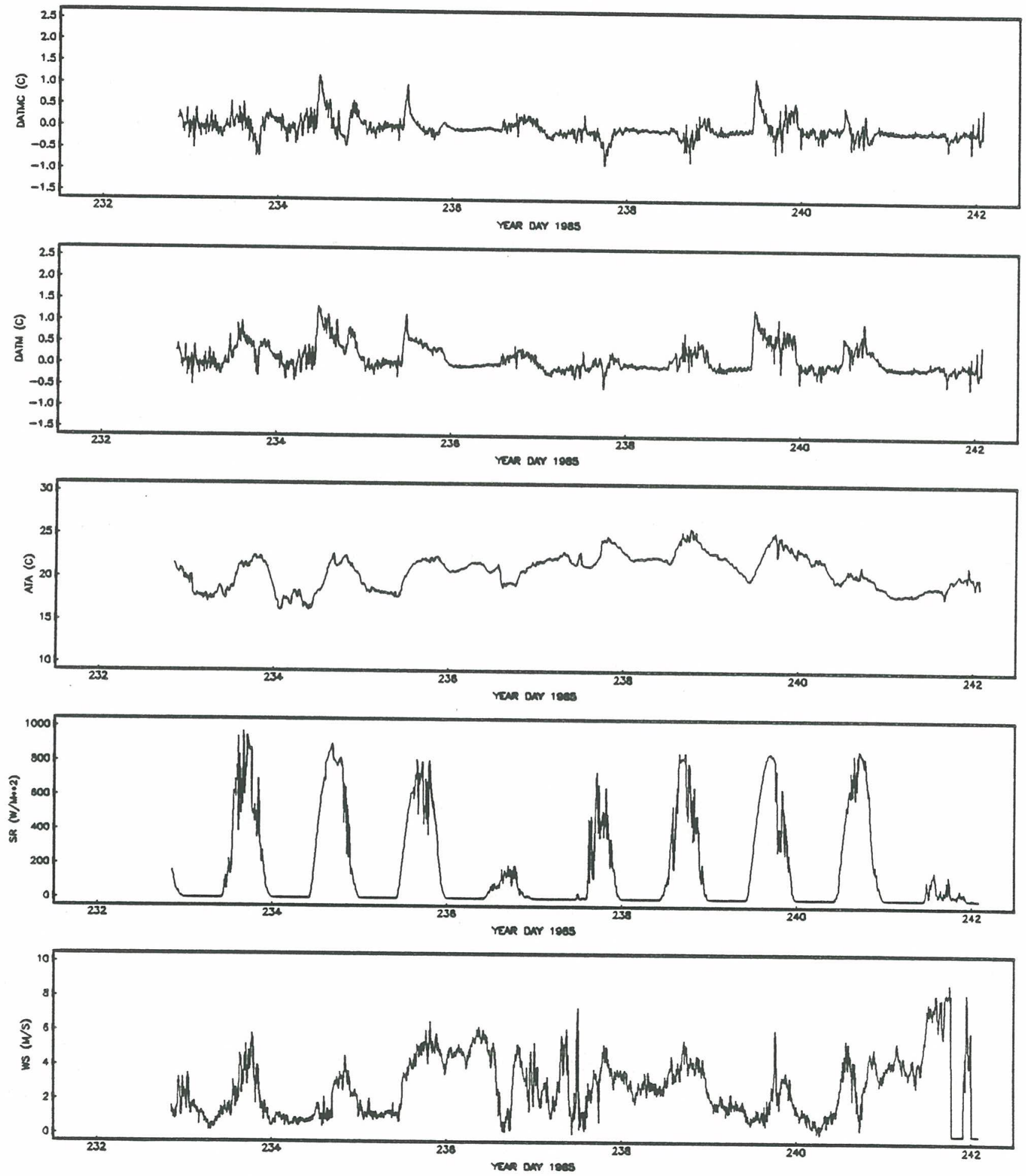

Figure 4 
8
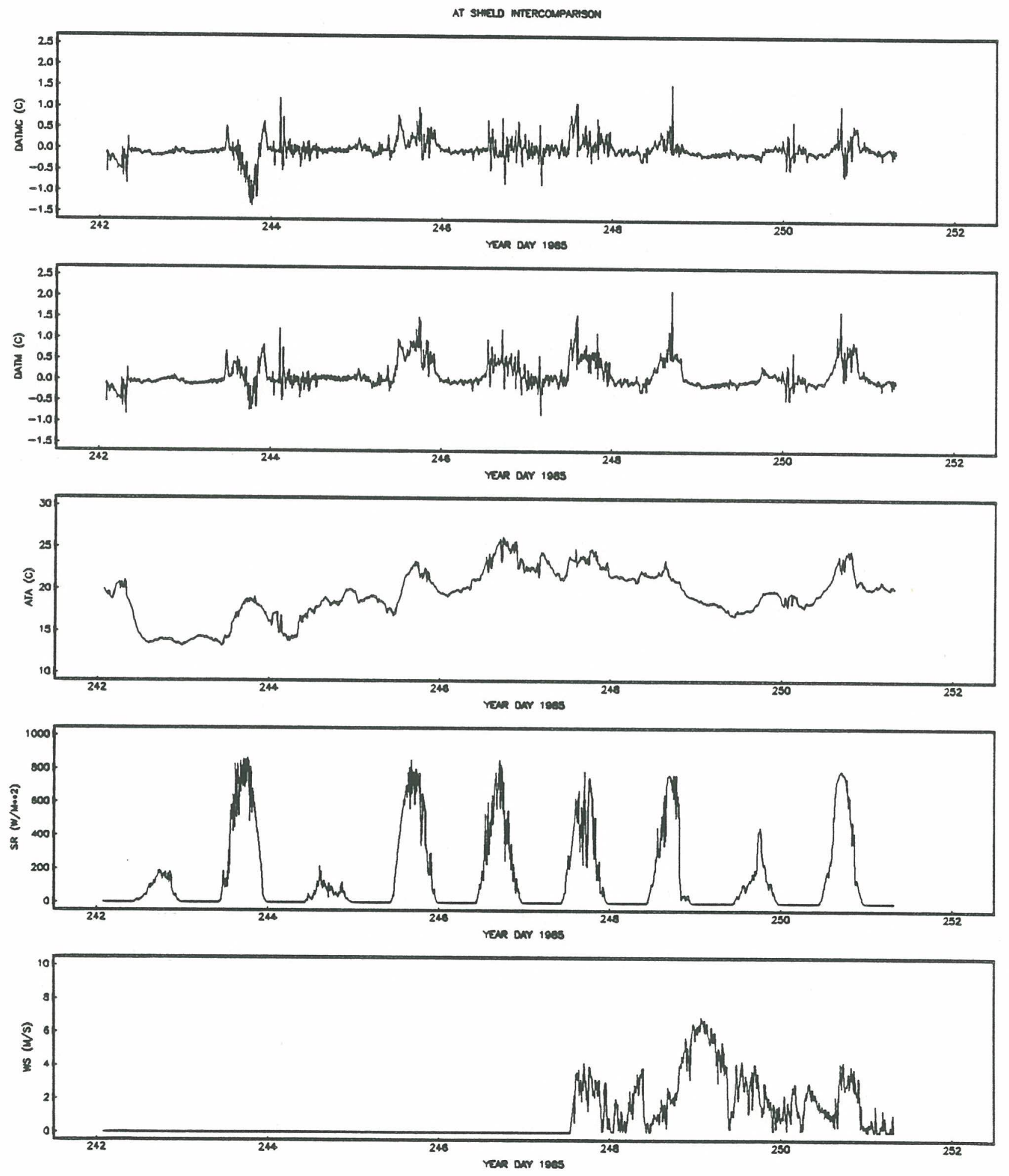

Figure 5 

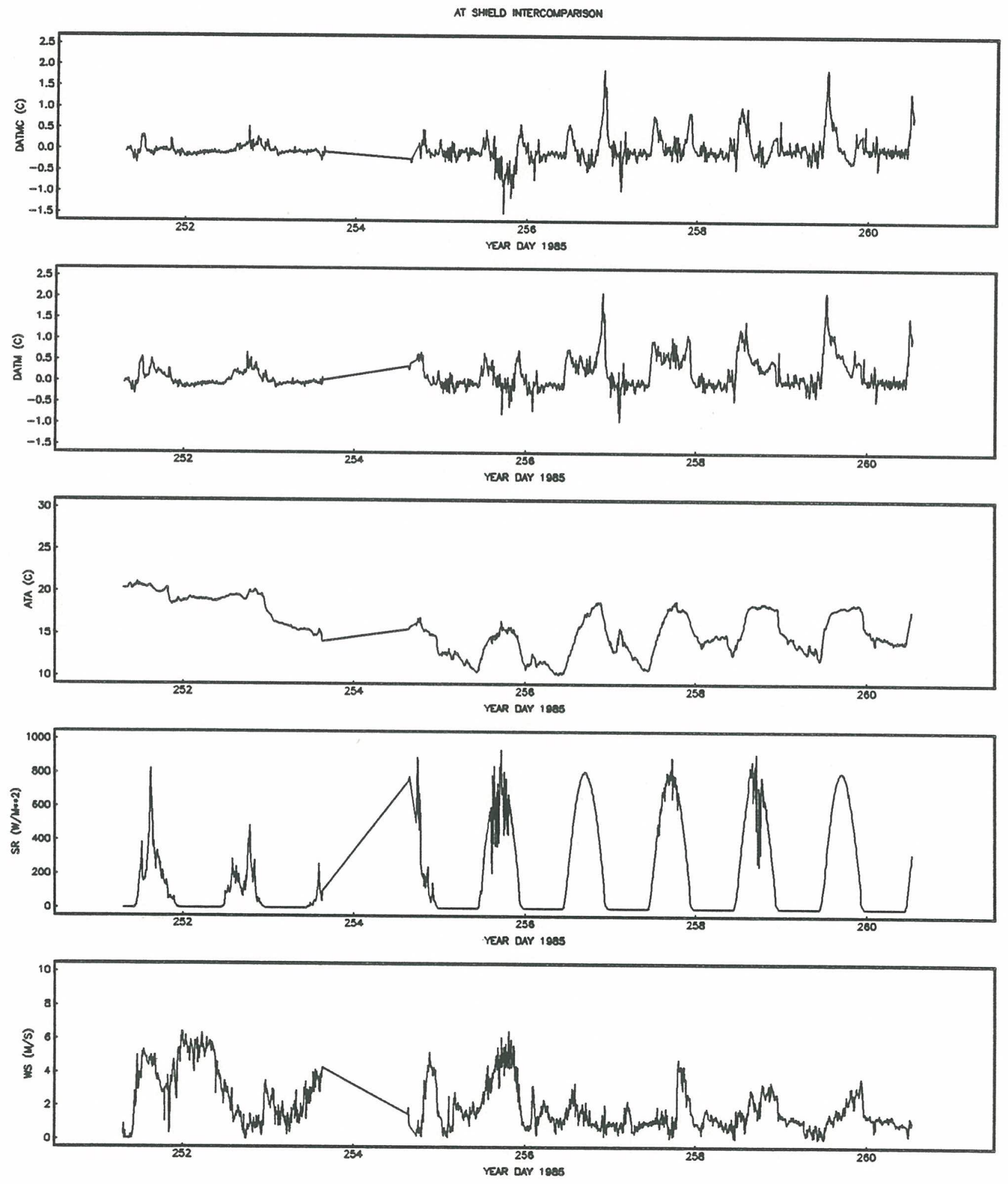

Figure 6 
AT SHED MTERCOMPARTSON
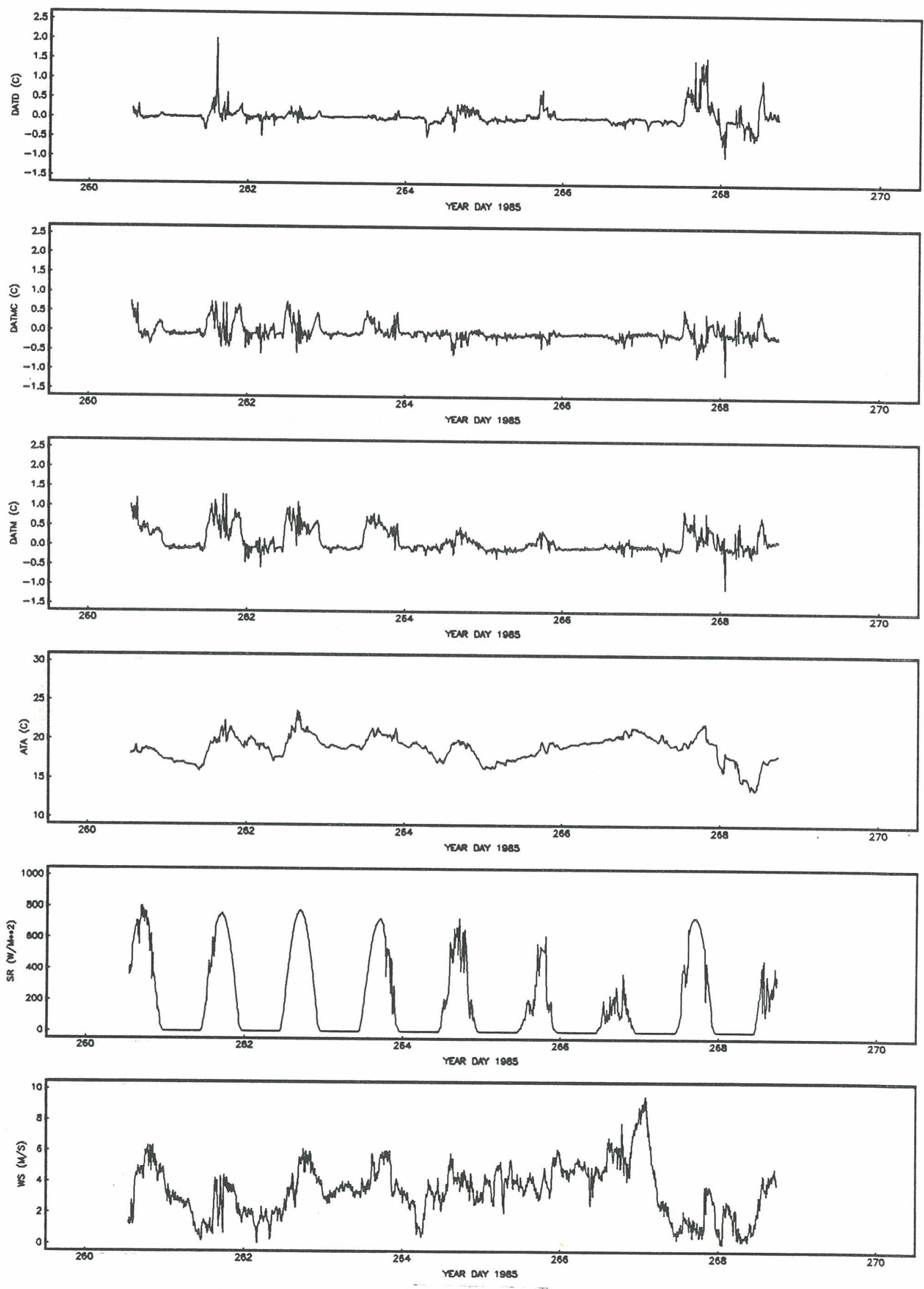
The aspirated air temperature contains a diurnal signal as is expected since air temperatures are normally higher during sunny days than at night. The diurnal signal in DATM and on particularly sunny days with low wind speed, in DATD shows that the aspirated sensor is measuring ambient air temperature better than either of the other two shields.

Data Analysis

Several secondary parameters were computed. Since there was a fairly substantial correlation (.63) between the multiplate temperature differences and solar irradiance we did a least squares fit between the two, obtaining the relation

$$
\mathrm{C}=0.012+0.7680 \mathrm{E}-03 * \mathrm{SR}
$$

where $\mathrm{SR}$ is irradiance in $\mathrm{w}^{-2}$. Subtracting this from the original multiplate temperatures gave air temperatures with at least a first order correction for the heating effects of the sun. Since we were interested in whether we could improve air temperatures from the multiplate shield with such a correction we added this parameter to the edited data file as DATMC. No consistent diurnal signal was apparent in the Dean shield temperatures (see Figure 7) so we did not attempt to correct these.

of primary interest are the errors in the measurements with the shields. The following quantities were computed and all further analysis used them:

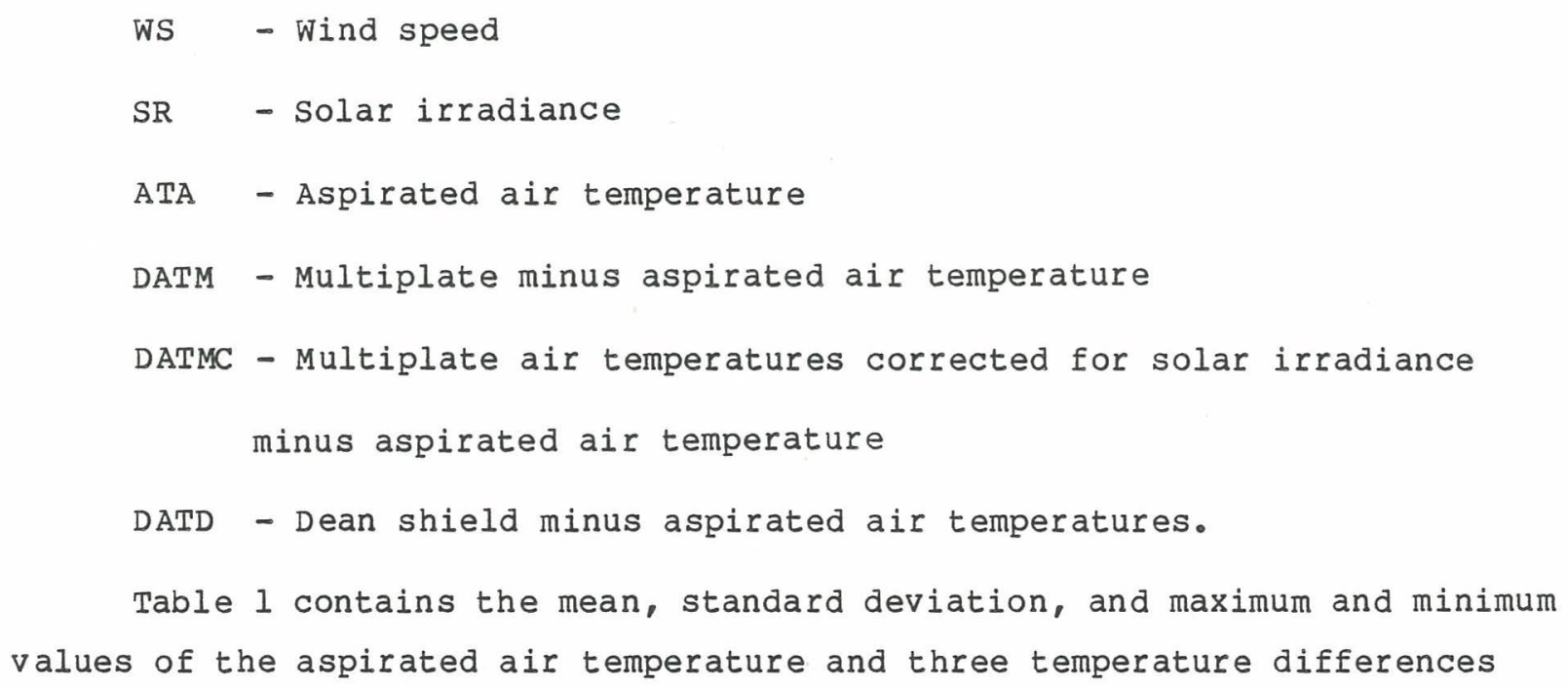


Table 1

DATA STATISTICS

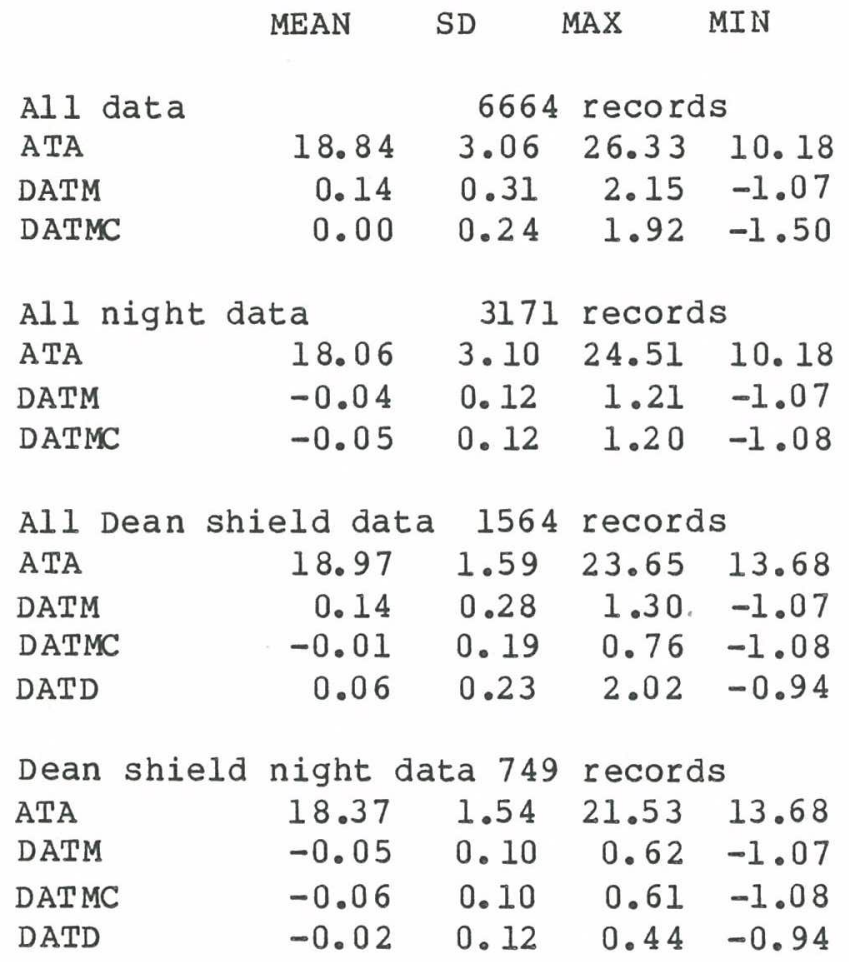


for the entire data set, where appropriate, and three subsets: night time (irradiance is less than $2 \mathrm{w} \mathrm{m}^{-2}$ ) values, full data set; all values during the period that the Dean shield data were recorded; night time (irradiance is less than $2 \mathrm{w} \mathrm{m}^{-2}$ ) values during the Dean shield period.

When averaged over the whole data set, DATMC is identically zero by definition since that is the data set over which the least squares fit was done. The standard deviation is definitely decreased by correcting for solar irradiance but the improvement is small, an order of magnitude less than we would like. Part of the reason for this is certainly an inadequate amount of data over sufficient ranges of the parameters. Also probably playing a part is a peculiarity of the local weather since Nantucket sound is decidedly in a sea breeze regime. The correlation between WS and SR is quite apparent in Figures 4-7, particularly on clear days. Since the maximum errors in the multiplate air temperatures occur when the wind speed is low, there are frequently peaks in DATM just after sunrise before the sea breeze has been established and just before sunset when the breeze has decreased. Because of the correlation between WS and SR we cannot separate the effects of these statistically. Qualitatively, however, it appears from this measure that there is a threshold in wS of the order of $2-3 \mathrm{~m} \mathrm{~s}^{-1}$ above which the errors in multiplate air temperatures are $0.5^{\circ} \mathrm{C}$ or less, and below which they can be much larger.

Gill (1983) describes a study in which he radiated an earlier version of the multiplate radiation shield with artificial solar radiation in a wind tunnel at wind speeds from nearly zero to $3 \mathrm{~m} \mathrm{~s}^{-1}$. He found sensor temperatures were elevated by $0.5^{\circ} \mathrm{C}$ at $3 \mathrm{~m} \mathrm{~s}^{-1}, 0.7^{\circ} \mathrm{C}$ at $2 \mathrm{~m} \mathrm{~s}^{-1}, 1.3^{\circ} \mathrm{C}$ at $1 \mathrm{~m} \mathrm{~s}^{-1}$, and up to $7^{\circ} \mathrm{C}$ at lower wind speeds. These values are reasonably consistent with ours.

Tables 2-4 and Figures 8-10 show a different representation of the same data. The temperature differences were divided into groups according to wind speed. Within each group we determined minimum and maximum values, the median value, and the upper and lower quartiles (25\% of values greater than upper quartile, $25 \%$ of values less than lower quartile). Table 2 gives these values for $1 \mathrm{~m} \mathrm{~s}^{-1}$ wind speed ranges for all DATM and DATMC temperature differences, during the full observation period. Table 3 gives the 
Table 2

Distribution of Parameters by Wind Speed

20 Aug to 25 Sep, All Data

\begin{tabular}{|c|c|c|c|c|c|c|c|c|}
\hline FILE & WS & NPTS & PARS & MIN & LQ & MED & UQ & MAX \\
\hline WI ND I & $0-1$ & 1055 & $\begin{array}{l}\text { WS } \\
\text { DATM } \\
\text { DATMC }\end{array}$ & $\begin{array}{c}.02 \\
-0.934 \\
-0.946\end{array}$ & $\begin{array}{l}0.44 \\
-0.145 \\
-0.81\end{array}$ & $\begin{array}{l}0.68 \\
0.051 \\
0.010\end{array}$ & $\begin{array}{l}0.87 \\
0.702 \\
0.380\end{array}$ & $\begin{array}{l}1.00 \\
2.129 \\
1.915\end{array}$ \\
\hline WIN D2 & $1-2$ & 1353 & $\begin{array}{l}\text { WS } \\
\text { DATM } \\
\text { DATMC }\end{array}$ & $\begin{array}{c}1.01 \\
-0.689 \\
-0.701\end{array}$ & $\begin{array}{c}1.21 \\
-0.050 \\
-0.077\end{array}$ & $\begin{array}{c}1.40 \\
0.343 \\
-0.007\end{array}$ & $\begin{array}{l}1.67 \\
0.703 \\
0.101\end{array}$ & $\begin{array}{l}2.00 \\
2.114 \\
1.909\end{array}$ \\
\hline WI ND3 & $2-3$ & 876 & $\begin{array}{l}\text { WS } \\
\text { DATM } \\
\text { DATMC }\end{array}$ & $\begin{array}{c}2.01 \\
-1.068 \\
-1.080\end{array}$ & $\begin{array}{c}2.27 \\
-0.051 \\
-0.096\end{array}$ & $\begin{array}{r}2.55 \\
0.010 \\
-0.042\end{array}$ & $\begin{array}{l}2.78 \\
0.361 \\
0.049\end{array}$ & $\begin{array}{l}3.00 \\
2.146 \\
1.549\end{array}$ \\
\hline WIN D4 & $3-4$ & 969 & $\begin{array}{l}\text { WS } \\
\text { DATM } \\
\text { DATMC }\end{array}$ & $\begin{array}{c}3.01 \\
-0.540 \\
-0.830\end{array}$ & $\begin{array}{l}3.25 \\
-0.040 \\
-0.095\end{array}$ & $\begin{array}{c}3.48 \\
0.083 \\
-0.043\end{array}$ & $\begin{array}{l}3.73 \\
0.406 \\
0.063\end{array}$ & $\begin{array}{l}4.00 \\
1.282 \\
0.710\end{array}$ \\
\hline WI ND5 & $4-5$ & 720 & $\begin{array}{l}\text { WS } \\
\text { DATM } \\
\text { DATMC }\end{array}$ & $\begin{array}{c}4.01 \\
-0.439 \\
-0.934\end{array}$ & $\begin{array}{c}4.23 \\
-0.042 \\
-0.114\end{array}$ & $\begin{array}{c}4.47 \\
0.043 \\
-0.062\end{array}$ & $\begin{array}{l}4.72 \\
0.306 \\
0.027\end{array}$ & $\begin{array}{l}5.00 \\
1.300 \\
0.709\end{array}$ \\
\hline WIN D6 & $5-6$ & 408 & $\begin{array}{l}\text { WS } \\
\text { DATM } \\
\text { DATMC }\end{array}$ & $\begin{array}{c}5.01 \\
-0.514 \\
-1.044\end{array}$ & $\begin{array}{c}5.21 \\
-0.071 \\
-0.129\end{array}$ & $\begin{array}{c}5.42 \\
-0.013 \\
-0.074\end{array}$ & $\begin{array}{c}5.63 \\
0.333 \\
-0.028\end{array}$ & $\begin{array}{l}6.00 \\
0.879 \\
0.415\end{array}$ \\
\hline WI NDX & $6-10$ & 195 & $\begin{array}{l}\text { WS } \\
\text { DATM } \\
\text { DATMC }\end{array}$ & $\begin{array}{c}6.01 \\
-0.762 \\
-1.495\end{array}$ & $\begin{array}{c}6.23 \\
-0.086 \\
-0.132\end{array}$ & $\begin{array}{c}6.74 \\
-0.011 \\
-0.068\end{array}$ & $\begin{array}{c}7.75 \\
0.028 \\
-0.019\end{array}$ & $\begin{array}{l}9.56 \\
0.582 \\
0.218\end{array}$ \\
\hline
\end{tabular}

MIN = MIN IMUM

LQ, UQ = LOWER, UPPER QUARTILE

MED = MEDIAN

MAX $=$ MAXIMUM 
Table 3

Distribution of Parameters by Wind Speed 20 Aug to $25 \mathrm{sep}$, Daytime data only, ( $\mathrm{SR}$ is greater than $2 \mathrm{w} \mathrm{m}^{-2}$ )

$\begin{array}{lllcccccc}\text { FILE } & \text { WS } & \text { PAR } & \text { NPTS } & \text { MIN } & \text { LQ } & \text { MED } & \text { UQ } & \text { MAX } \\ & & & & & & & & \\ \text { WIND1 } & 0-1 & \text { WS } & 382 & 0.02 & 0.49 & 0.74 & 0.89 & 1.00 \\ & & \text { DATM } & 382 & -0.439 & 0.145 & 0.378 & 0.684 & 2.129 \\ & & \text { DATMC } & 382 & -0.846 & -0.034 & 0.195 & 0.338 & 1.915 \\ \text { WIND2 } & 1-2 & \text { WS } & 595 & 1.01 & 1.23 & 1.45 & 1.69 & 2.00 \\ & & \text { DATM } & 595 & -0.288 & 0.174 & 0.430 & 0.670 & 2.114 \\ & & \text { DATMC } & 595 & -0.631 & -0.020 & 0.098 & 0.329 & 1.909 \\ \text { WIND3 } & 2-3 & \text { WS } & 469 & 2.01 & 2.28 & 2.56 & 2.80 & 3.00 \\ & & \text { DATM } & 469 & -0.179 & 0.085 & 0.326 & 0.534 & 2.146 \\ & & \text { DATMC } & 469 & -0.624 & -0.079 & 0.013 & 0.188 & 1.549 \\ \text { WI ND4 } & 3-4 & \text { WS } & 672 & 3.01 & 3.25 & 3.49 & 3.74 & 4.00 \\ & & \text { DATM } & 672 & -0.540 & 0.059 & 0.242 & 0.523 & 1.282 \\ & & \text { DATMC } & 672 & -0.830 & -0.094 & -0.011 & 0.199 & 0.710 \\ \text { WIND5 } & 4-5 & \text { WS } & 473 & 4.01 & 4.23 & 4.44 & 4.70 & 5.00 \\ & & \text { DATM } & 473 & -0.439 & 0.045 & 0.205 & 0.386 & 1.300 \\ & & \text { DATMC } & 473 & -0.934 & -0.150 & -0.066 & 0.011 & 0.709 \\ \text { WIND6 } & 5-6 & \text { WS } & 229 & 5.01 & 5.18 & 5.40 & 5.61 & 6.00 \\ & & \text { DATM } & 229 & -0.514 & 0.000 & 0.233 & 0.397 & 0.879 \\ & & \text { DATMC } & 229 & -1.044 & -0.166 & -0.076 & -0.010 & 0.415 \\ \text { WIND7 } & 6-9 & \text { WS } & 104 & 6.01 & 6.30 & 6.89 & 7.45 & 8.75 \\ & & \text { DATM } & 104 & -0.762 & -0.038 & 0.013 & 0.044 & 0.582 \\ & & \text { DATMC } & 104 & -1.495 & -0.158 & -0.079 & -0.039 & 0.072\end{array}$


Table 4

Distribution of Parameters by Wind Speed 17-25 Sep, Daytime data only ( $\mathrm{SR}$ is greater than $2 \mathrm{w} \mathrm{m}^{-2}$ )

\begin{tabular}{|c|c|c|c|c|c|c|c|c|}
\hline FILE & WS & PAR & NPTS & MIN & LQ & MED & UQ & MAX \\
\hline \multirow[t]{4}{*}{ WINDI } & $0-1$ & WS & 53 & 0.22 & 0.61 & 0.78 & 0.87 & 0.98 \\
\hline & & DATM & 53 & -0.150 & -0.029 & 0.178 & 0.485 & 1.025 \\
\hline & & DAT MC & 53 & -0.423 & -0.141 & -0.084 & 0.035 & 0.615 \\
\hline & & DATD & 53 & -0.46 & -0.09 & 0.36 & 0.96 & 1.75 \\
\hline \multirow[t]{4}{*}{ WIN D2 } & $1-2$ & WS & 97 & 1.01 & 1.22 & 1.41 & 1.68 & 1.99 \\
\hline & & DATM & 97 & -0.108 & 0.218 & 0.522 & 0.636 & 1.150 \\
\hline & & DAT MC & 97 & -0.631 & -0.036 & 0.186 & 0.382 & 0.750 \\
\hline & & DATD & 97 & -0.45 & 0.06 & 0.21 & 0.51 & 2.02 \\
\hline \multirow[t]{4}{*}{ WIN D3 } & $2-3$ & WS & 68 & 2.03 & 2.41 & 2.64 & 2.82 & 2.99 \\
\hline & & DATM & 68 & -0.168 & 0.054 & 0.153 & 0.682 & 0.991 \\
\hline & & DAT MC & 68 & -0.556 & -0.029 & 0.049 & 0.445 & 0.760 \\
\hline & & DATD & 68 & -0.15 & 0.04 & 0.10 & 0.24 & 1.04 \\
\hline \multirow[t]{4}{*}{ WIN D4 } & $3-4$ & WS & 238 & 3.01 & 3.34 & 3.55 & 3.79 & 4.00 \\
\hline & & DATM & 238 & -0.119 & 0.083 & 0.256 & 0.540 & 1.282 \\
\hline & & DATMC & 238 & -0.416 & -0.074 & 0.002 & 0.231 & 0.710 \\
\hline & & DATD & 238 & -0.08 & 0.04 & 0.10 & 0.19 & 1.18 \\
\hline \multirow[t]{4}{*}{ WIN D5 } & $4-5$ & WS & 195 & 4.01 & 4.23 & 4.47 & 4.71 & 5.00 \\
\hline & & DATM & 195 & -0.212 & 0.071 & 0.196 & 0.432 & 1.300 \\
\hline & & DATMC & 195 & -0.365 & -0.139 & -0.062 & 0.017 & 0.709 \\
\hline & & DATD & 195 & -0.08 & 0.00 & 0.04 & 0.11 & 0.38 \\
\hline \multirow[t]{4}{*}{ WIN D6 } & $5-6$ & WS & 125 & 5.01 & 5.25 & 5.49 & 5.67 & 6.00 \\
\hline & & DATM & 125 & -0.217 & 0.051 & 0.328 & 0.440 & 0.836 \\
\hline & & DATMC & 125 & -0.595 & -0.133 & -0.065 & 0.001 & 0.360 \\
\hline & & DATD & 125 & -0.33 & -0.03 & 0.00 & 0.02 & 0.09 \\
\hline \multirow[t]{4}{*}{ WIN D7 } & $6-8$ & WS & 40 & 6.01 & 6.18 & 6.31 & 6.62 & 7.82 \\
\hline & & DATM & 40 & -0.204 & -0.015 & 0.018 & 0.055 & 0.520 \\
\hline & & DAT MC & 40 & -0.362 & -0.175 & -0.108 & -0.049 & 0.072 \\
\hline & & DATD & 40 & -0.20 & -0.08 & -0.03 & 0.00 & 0.07 \\
\hline
\end{tabular}


17

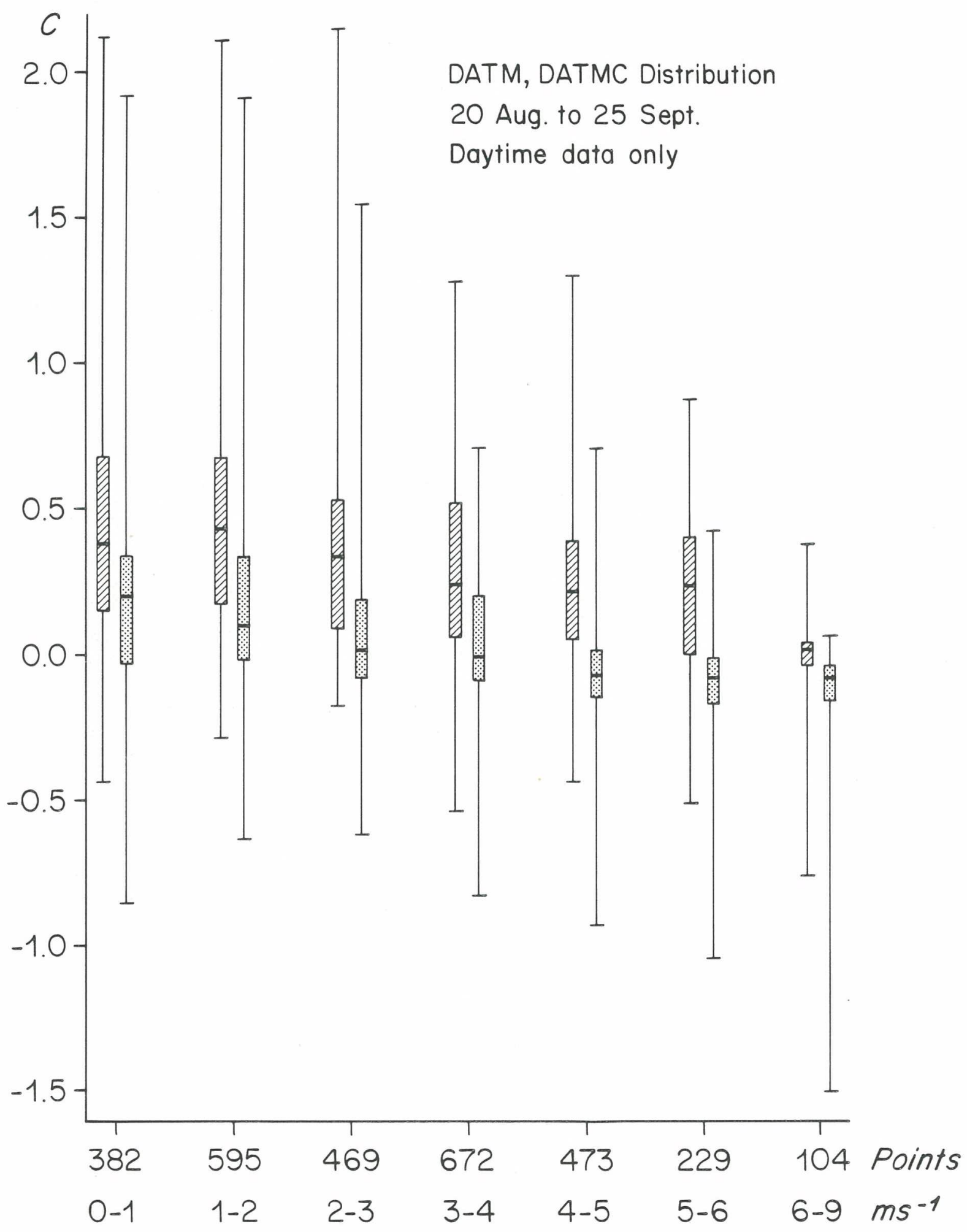

Figure 8 


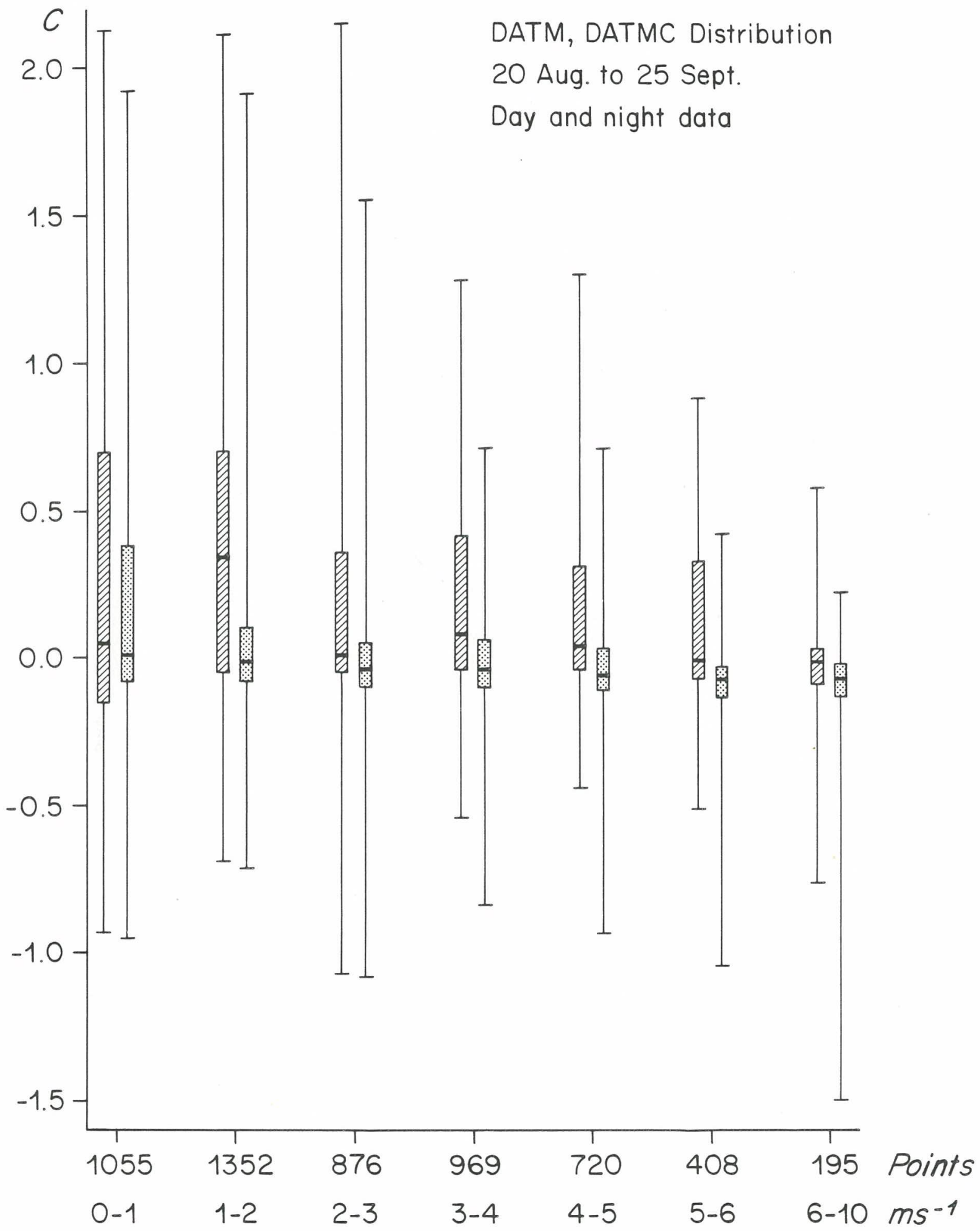

Figure 9 


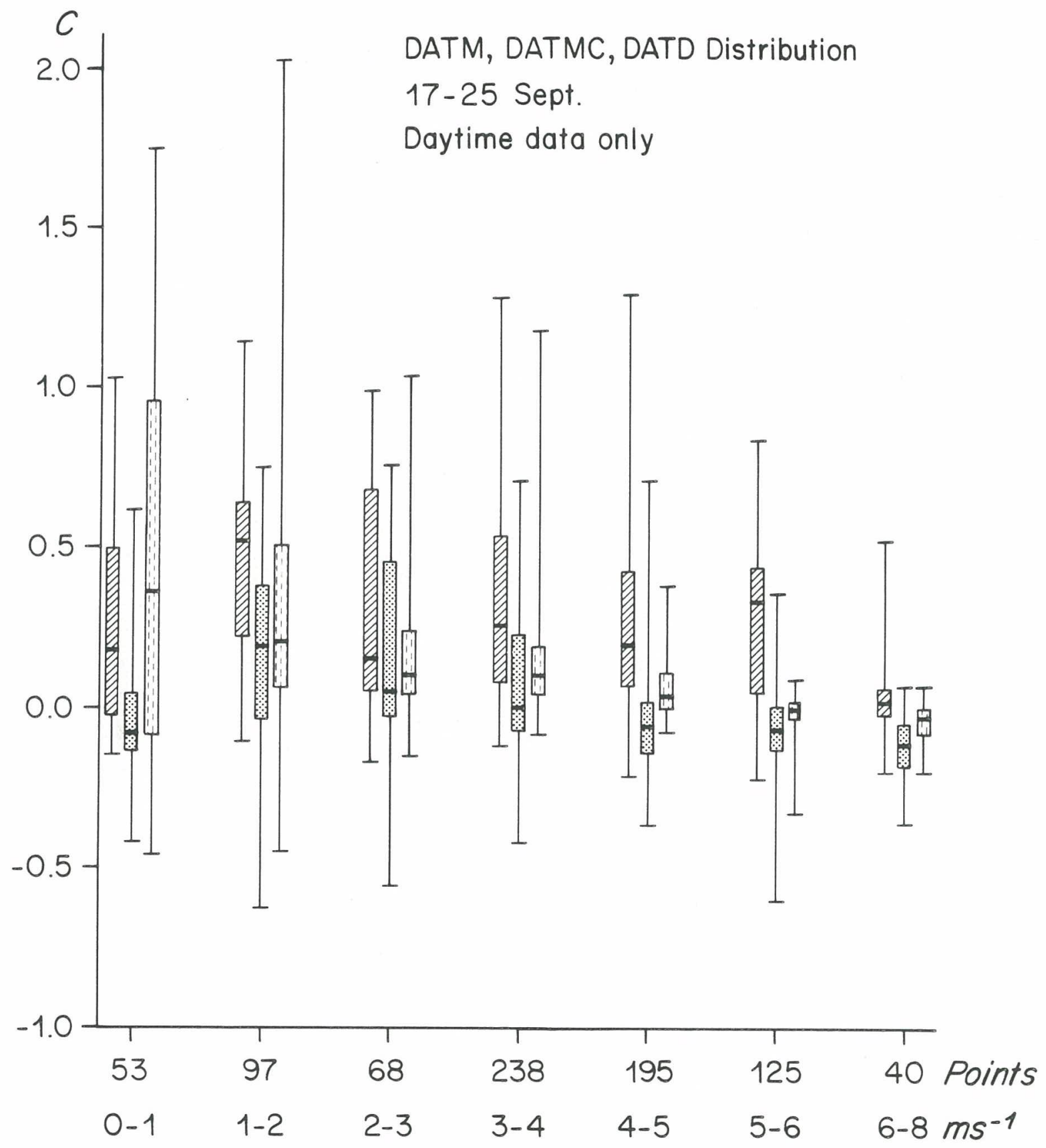

Figure 10 
values for daytime ( $S R$ is greater than $2 \mathrm{w} \mathrm{m}^{-2}$ ) DATM and DATMC only. Table 4 gives the values for daytime DATM, DATMC, and DATD for the period when the Dean sensor was connected. Figures 8-10 are box plots of the same numbers. The boxes give the upper and lower quartiles; thus the line toward the middle of a box indicates the median. Fifty per cent of the values in a wind speed range lie within a box. Below each box are given the wind speed range and the number of samples in that speed range.

For ideal shields the boxes in Figures 8-10 would all collapse on zero. It is apparent that the correction does improve the temperatures from the multiplate shield since, for all wind speed ranges on all plots the median is closer to zero and the extent of the box is decreased for the corrected values. The improvement is most apparent on Figures 8, 9 although it is perceivable even in the reduced data set represented on Figure 10. The performance of both types of radiation shields improves with increasing wind speed. For wind speeds greater than $6 \mathrm{~m} \mathrm{~s}^{-1}$, the performance of both types appears to be equivalent. In the wind speed range $2-6 \mathrm{~m} \mathrm{~s}^{-1}$, the Dean shield seems to protect the thermistor better than the multiplate shield. For wind speeds less than $2 \mathrm{~m} \mathrm{~s}^{-1}$, the multiplate shield does better, presumably because at these low speeds there is not enough wind force on the Dean shield to overcome the bearing friction and turn it into the wind.

\section{Conclusions}

We have presented the results of an informal study of the performance of R. M. Young multiplate radiation shields and a shield designed and constructed at WHOI (Dean shield). Both shields gave errors of up to $1-2^{\circ} \mathrm{C}$, however the Dean shield seemed to perform better in wind speeds of more than $2 \mathrm{~m} \mathrm{~s}^{-1}$. The error in air temperature measurement by a thermistor in either type of shield depends on both solar radiation and wind speed the error increasing with increasing solar irradiance and decreasing with increasing wind speed. It may be possible to generate a meaningful correction to air temperatures measured with the multiplate radiation shield which is a function of irradiance and wind speed. A correction based on data recorded in this study makes a noticeable improvement in air temperature measurement 
accuracy. The small range in values of irradiance and wind speed and the correlation between irradiance and wind speed means that the correction we have derived is much less than optimal. A better correction would require a much more extensive study. 
References

Dean, J., and R. C. Beardsley, 1987. A vector averaging wind recorder (VAWR) for surface meteorological measurements in CODE. Woods Hole oceano. Inst. Tech. Rept., in preparation.

Gill, G. C., 1983. Comparison testing of selected naturally ventilated solar radiation shields. Report submitted to NOAA Data Buoy Office, Bay St. Louis, Miss. In partial fulfillment of Contract \#NA-82-0A-A-266, September 1983.

Payne, R. E., 1987. The MR, a meteorological data sensing, , recording, and telemetering package for use on moored buoys. J. of Atmos. and Oceanic Tech., accepted.

Payne, R. E•, A. L. Bradshaw, J. P. Dean, K. E. Schleicher, 1976. Accuracy of temperature measurements with the VACM. Woods Hole Oceano. Inst. Tech. Rept. 76-94, (unpublished manuscript). 


\section{DOCUMENT LIBRARY}

August 21, 1987

\section{Distribution List for Technical Report Exchange}

Attn: Stella Sanchez-Wade

Documents Section

Scripps Institution of Oceanography

Library, Mail Code C-075C

La Jolla, CA 92093

Hancock Library of Biology \& Oceanography

Alan Hancock Laboratory

University of Southern California

University Park

Los Angeles, CA 90089-0371

Gifts \& Exchanges

Library

Bedford Institute of Oceanography

P.O. Box 1006

Dartmouth, NS, B2Y 4A2, CANADA

Office of the International Ice Patrol

c/o Coast Guard R \& D Center

Avery Point

Groton, CT 06340

Library

Physical Oceanographic Laboratory

Nova University

8000 N. Ocean Drive

Dania, FL 33304

NOAA/EDIS Miami Library Center

4301 Rickenbacker Causeway

Miami, FL 33149

Library

Skidaway Institute of Oceanography

P.O. Box 13687

Savannah, GA 31416

Institute of Geophysics

University of Hawaii

Library Room 252

2525 Correa Road

Honolulu, HI 96822

Library

Chesapeake Bay Institute

4800 Atwell Road

Shady Side, MD 20876

MIT Libraries

Serial Journal Room 14E-210

Cambridge, MA 02139
Director, Ralph M. Parsons Laboratory

Room 48-311

MIT

Cambridge, MA 02139

Marine Resources Information Center

Building E38-320

MIT

Cambridge, MA 02139

Library

Lamont-Doherty Geological Observatory

Colombia University

Palisades, NY 10964

Library

Serials Department

Oregon State University

Corvallis, OR 97331

Pell Marine Science Library

University of Rhode Island

Narragansett Bay Campus

Narragansett, RI 02882

Working Collection

Texas A\&M University

Dept. of Oceanography

College Station, TX 77843

Library

Virginia Institute of Marine Science

Gloucester Point, VA 23062

Fisheries-Oceanography Library

151 Oceanography Teaching Bldg.

University of Washington

Seattle, WA 98195

Library

R.S.M.A.S.

University of Miami

4600 Rickenbacker Causeway

Miami, FL 33149

Maury Oceanographic Library

Naval Oceanographic Office

Bay St. Louis

NSTL, MS 39522-5001 


\begin{tabular}{|c|c|c|c|}
\hline $\begin{array}{l}\text { REPORT DOCUMENTATION } \\
\text { PAGE }\end{array}$ & $\begin{array}{l}\text { 1. REPORT NO. } \\
\qquad \mathrm{WHOI}-87-40\end{array}$ & 2. & 3. Recipient's Accession No. \\
\hline \multirow{2}{*}{\multicolumn{2}{|c|}{$\begin{array}{l}\text { 4. Title and Subtitle } \\
\text { Air Temperature Shield Tests }\end{array}$}} & & $\begin{array}{l}\text { 5. Report Date } \\
\text { October } 1987\end{array}$ \\
\hline & & & 6. \\
\hline \multicolumn{3}{|l|}{$\begin{array}{l}\text { 7. Author(s) } \\
\text { Richard E. Payne }\end{array}$} & $\begin{array}{l}\text { 8. Performing Organization Rept. No. } \\
\text { WHOI-87-40 }\end{array}$ \\
\hline \multicolumn{3}{|c|}{ 9. Performing Organization Name and Address } & 10. Project/Task/Work Unit No. \\
\hline \multicolumn{3}{|c|}{$\begin{array}{l}\text { Woods Hole Oceanographic Institution } \\
\text { Woods Hole, Massachusetts } 02543\end{array}$} & $\begin{array}{l}\text { 11. Contract(C) or Grant(G) No. } \\
\text { (C) NO0014-84-C-0134 } \\
\text { (G) OCE } 8122061 \\
\text { OCE } 8211108\end{array}$ \\
\hline \multicolumn{3}{|c|}{ 12. Sponsoring Organization Name and Address } & $\begin{array}{l}\text { 13. Type of Report \& Period Covered } \\
\text { Technical }\end{array}$ \\
\hline \multicolumn{2}{|c|}{ National Science Foundation } & & 14. \\
\hline
\end{tabular}

15. Supplementary Notes

This report should be cited as: Woods Hole Oceanog. Inst. Tech. Rept., WHOI-87-40.

16. Abstract (Limit: 200 words)

Measurements were made with a group of sensors for 37 days at the end of a dock in Vineyard Sound. The sensors included: a thermistor in an R. M. Young aspirated air temperature radiation shield, a thermistor in an R. M. Young multiplate shield, wind speed and direction, and solar irradiance. For the last eight days we also included a WHOI built cylindrical radiation shield. For wind speeds above $2 \mathrm{~m} \mathrm{~s}^{-1}$, the multiplate shield had an RMS error relative to the aspirated shield of 0.2-0.3 C during daylight hours. Adding a correction linear in solar irradiance decreased the error by a factor of one third to one half. The cylindrical shield appears to have performed better than this but there was insufficient data to support this conclusion statistically.

17. Document Analysis a. Descriptors

1. air temperature shield

2. meteorology

b. Identifiers/Open-Ended Terms

c. COSATI FIeld/Group

18. Availability Statemen:

Approved for publication; distribution unlimited.

19. Security Class (This Report) UNCLASSIFIED

20. Security Class (This Page)
21. No. of Pages 22 